\title{
DEVELOPMENT AND SURVIVAL RATE OF GIANT SHRIMP LARVA (Macrobrachium rosebergii de Man) GIMacro II AT DIFFERENT SALINITIES
}

\author{
Deny Sapto Chondro Utomo ${ }^{1}$. Wardiyanto ${ }^{1}$. Triando \\ Kurniawan $^{1}$
}

Ringkasan GIMacro II prawn larvae is able to grow well at a salinity of 815 ppt. This condition can be improved by improving the methods of adaptation to changes in salinity prawn larvae production activities, by determining the pattern of changes in salinity are right. Salinity media through osmotic pressure affect the physiological activity, where the cells in body organs prawns should be in liquid media with ionic composition and concentration of the same with the environment. Having obtained the optimum salinity on larval rearing prawns GIMacro II in different salinity media is expected to produce a population of prawns GIMacro II with superior durability specific to environmental conditions, which can then be directed to improve the utilization of marine resources to the salinity of the best. This research aims were to study the growth and survival of larvae prawns GIMacro II reared on media of different salinities. The study used completely randomized design with three treatments and three replications. The treatments were larval rearing prawns

\footnotetext{
${ }^{1}$ )Department of Aquaculture University of Lampung E-mail: deny.utomo@fp.unila.ac.id
}

GIMacro II at different salinities (10 ppt, 12 ppt, and 14 ppt). The results showed that the culture of prawn larvae GIMacro II at different salinity affect significantly on growth and survival of larvae prawns GIMacro II. The highest development of GIMacro II prawn larvae obtained from 12 ppt salinity treatment $(7.13 \pm 0.03 \%)$ and the highest survival rate was obtained also from 12 ppt salinity treatment (67.67 \pm $4.51 \%)$

Keywords Macrobrachium rosebergii, larvae, salinity

Received : 07 Juli 2018

Accepted : 13 Agustus 2018

\section{PENDAHULUAN}

Udang Galah (Macrobrachium rosenbergii de Man) merupakan salah satu komoditas perikanan yang bernilai ekonomis tinggi. Selain mempunyai ukuran terbesar diban- dingkan dengan udang air tawar lainnya, udang galah juga sangat di- gemari konsumen baik di dalam maupun di luar negeri terutama di Jepang dan beberapa Negara Eropa (Priyono et al., 2011). 
Dalam kegiatan budidaya udang galah, faktor kualitas air, termasuk di dalamnya salinitas media, merupakan faktor yang sangat mempengaruhi kehidupan udang galah. Salinitas media, melalui tekanan osmotiknya, mempengaruhi aktivitas fisiologis, baik pada osmoregulasi maupun bioenergetik. Apabila tekanan osmotik media (salinitas) berbeda jauh dengan tekanan osmotik cairan tubuh (kondisi tidak ideal) maka perbedaan tekanan osmotik akan menjadi beban bagi udang sehingga dibutuhkan energi yang relatif besar untuk mempertahankan osmotik tubuhnya agar tetap pada keadaan yang ideal.

Salinitas termasuk ke dalam kelompok masking factor yaitu faktor-faktor yang dapat memodifikasi pengaruh faktor lingkungan lain menjadi satu kesatuan pengaruh osmotik melalui suatu mekanisme pengaturan tubuh organisme. Salinitas media melalui tekanan osmotiknya mempengaruhi aktivitas fisiologis, salah satunya osmoregulasi, dimana selsel pada organ tubuh harus berada dalam cairan media dengan konsentrasi ionik yang sama dengan lingkungannya. Oleh karena itu diperlukan pengaturan (osmoregulasi) agar tercipta konsentrasi ionik cairan dalam sel dengan cairan luar sel yang hampir sama $(\mathrm{Nu}-$ grahaningsih, 2008). Oleh karena itu, salinitas media akan mempengaruhi penggunaan energi untuk osmoregulasi (Ali and Waluyo, 2015).

Penggunaan energi yang besar dalam proses osmoregulasi pada udang galah menyebabkan terhambatnya perkembangan dan tingginya mortalitas udang galah. Sehingga perlu dilakukan penelitian untuk mencari pola-pola perubahan kebutuhan salinitas dari penetasan hingga post larva, untuk mendapatkan salinitas optimum yang menghasilkan kelangsungan hidup dan pertumbuhan larva udang galah GIMacro II yang terbaik.

\section{MATERI DAN METODE}

Penelitian ini dilaksanakan pada bulan Oktober - November 2016 bertempat di Balai Penelitan dan Pemuliaan Ikan, Sukamandi, Subang, Jawa Barat. Alatalat yang digunakan antara lain: bak fiber kerucut, akuarium ukuran $0,3 \times 0,3 \times 0,3$ $\mathrm{m}$, blower, refraktometer, termometer, DO meter, $\mathrm{pH}$ meter, timbangan digital, plankton net, alat tulis, mangkok plastik, penggaris, kertas label. Sedangkan bahan yang digunakan adalah larva udang galah GIMacro II, air tawar, dan air laut.

Rancangan yang digunakan dalam penelitian ini adalah rancangan acak lengkap (RAL) yang terdiri atas 3 perlakuan dengan 3 kali ulangan. Perlakuan yang digunakan adalah sebagai berikut

1. Perlakuan $\mathrm{A}=$ Pemeliharaan larva udang galah GIMacro II dengan salinitas 10 ppt.

2. Perlakuan $\mathrm{B}=$ Pemeliharaan larva udang galah GIMacro II dengan salinitas 12 ppt.

3. Perlakuan $\mathrm{C}=$ Pemeliharaan larva udang galah GIMacro II dengan salinitas 14 ppt.

Larva udang galah yang didapatkan dari hasil pemijahan dipindahkan ke masingmasing media pemeliharaan sesuai dengan perlakuan yang diberikan. Masingmasing ulangan diisi udang galah sebanyak 300 ekor. Selama 21 hari pemeliharaan, larva udang galah diberikan pakan Artemia sp. dengan frekuensi 
2 kali sehari sebanyak 20 - 80 individu/larva/hari.

Parameter yang diamati adalah kelangsungan hidup, laju perkembangan larva, dan kualitas air. Parameter kelangsungan hidup dan laju perkembangan larva dianalisis menggunakan uji Anova dengan tingkat kepercayaan $95 \%$ dan jika terdapat perbedaan nyata antar perlakuan, diuji lanjut menggunakan uji Duncan.

\section{HASIL DAN PEMBAHASAN}

Tahap perkembangan larva diamati setelah larva berumur 1 hari dan dimasukkan ke dalam wadah pemeliharaan. Perkembangan larva udang galah dapat dilihat pada Gambar 1. Perkembangan tertinggi terjadi pada pelakuan B yaitu sebesar 7,13 $\pm 0,03 \%$, kemudian diikuti dengan perlakuan A sebesar 6,97 $\pm 0,06 \%$ dan perlakuan $\mathrm{C}$ sebesar 6,86 $\pm 0,06 \%$ (Gambar 2).

Berdasarkan analisis statistik (Anova) dengan tingkat kepercayaan $95 \%$, perbedaan salinitas berpengaruh nyata $(\mathrm{P}<0,05)$ terhadap perkembangan larva udang galah GIMacro II stadia 1 hingga post larvae. Rata-rata perkembangan perlakuan B dengan nilai osmolaritas pada media sebesar $323 \mathrm{mmol} / \mathrm{kg}$ lebih baik dibandingkan perlakuan A dengan nilai osmolaritas yang ada pada media sebesar $311 \mathrm{mmol} / \mathrm{kg}$ dan $\mathrm{C}$ dengan nilai osmolaritas media sebesar $335 \mathrm{mmol} / \mathrm{kg}$. Ali and Waluyo (2015) menyatakan bahwa larva akan hidup dengan baik pada media dengan kisaran salinitas 3 12 ppt. Salinitas juga berhubungan erat dengan osmoregulasi hewan air. Perbedaan perkembangan stadia yang dilalui tiap-tiap perlakuan terjadi dikarenakan

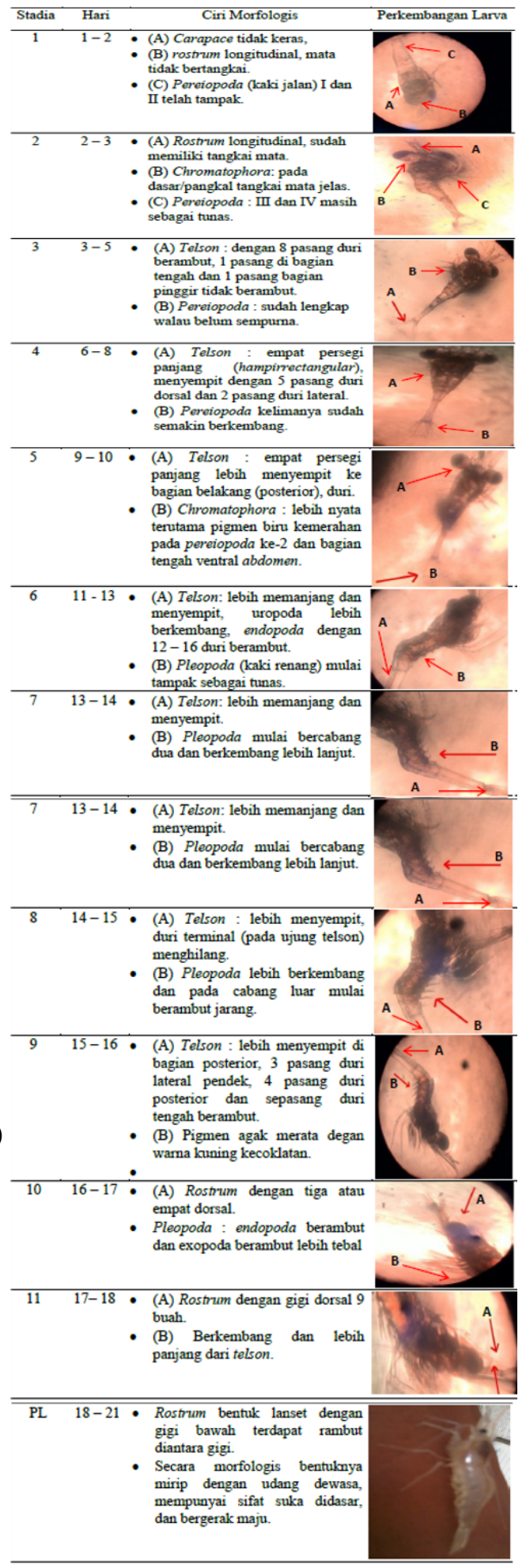

Gambar 1 Perkembangan larva udang galah (Macrobrachium rosenbergii) GIMacro II 




Gambar 2 Indeks perkembangan stadia larva udang galah

penerapan salinitas yang berbeda-beda menuntut larva untuk beradaptasi dengan osmoregulasi, kondisi ini diyakini mempengaruhi beban kerja osmotik larva (Zikri et al., 2014). Hal ini sesuai dengan pernyataan Hana (2007) yang menyatakan bahwa perbedaan perkembangan ini diduga akibat perbedaan kemampuan pengaturan osmotik dan ionik, yang secara fisiologis harus terjadi untuk mempertahankan keadaan steady state dan aktivitas ini memerlukan energi metabolisme, sehingga akan terjadi pula perbedaan proses-proses pembentukan jaringan tubuh. Semakin besar beban osmotik, maka semakin lama waktu yang dibutuhkan larva udang galah untuk berubah stadia (Syafei, 2006).

Pada saat larva udang sedang dalam masa perkembangan stadia, larva mengalami masa kritis yang cukup tinggi. Terlebih lagi saat peralihan ke post larvae. Masa kritis larva udang juga dialami saat terjadinya moulting (pergantian kulit) (Mukti and Satyantini, 2016). Perkembangan larva udang galah GIMacro II selama 21 hari pemeliharaan pada penelitian ini dapat dikatakan tinggi jika dibandingkan pada pembe- nihan umumnya yang biasanya mencapai 25 - 30 hari. Hal tersebut diduga karena larva udang galah GIMacro II dapat mempertahankan tekanan osmotik yang ada pada lingkungan. Supono (2017) menyatakan bahwa jika terjadi perbedaan tekanan osmotik pada hemolim udang dan air kolam yang besar menyebabkan udang akan banyak kehilangan energi untuk adaptasi sehingga perkembangan menjadi lambat. Kualitas air yang baik akan mendukung perkembangan yang optimal. Sebaliknya, kualitas air yang jelek akan menurunkan nafsu makan udang yang berakibat terhambatnya perkembangan larva udang galah GIMacro II. Perubahan kualitas air yang terlalu signifikan akan menyebabkan stres pada udang bahkan akan menyebabkan mortalitas pada udang yang pada akhirnya dapat menurunkan biomasa udang yang dipelihara (Supono, 2017).

Kelangsungan hidup merupakan parameter yang dapat menunjukkan presentase organisme yang mampu bertahan hidup pada akhir penelitian. Berdasarkan hasil penelitian selama 21 hari, tingkat kelangsungan hidup udang galah GIMacro II menunjukkan hasil yang berbeda untuk setiap perlakuan. Tingkat kelangsungan hidup tertinggi terjadi pada pelakuan B yaitu sebesar $67,67 \pm$ $4,51 \%$, kemudian diikuti dengan perlakuan $\mathrm{C}$ sebesar 56,00 $\pm 3,61 \%$, dan perlakuan A sebesar 50,67 \pm 4,51 (Gambar 3).

Berdasarkan analisis uji Anova dengan tingkat kepercayaan $95 \%$, perbedaan salinitas berpengaruh nyata $(\mathrm{P}<0,05)$ terhadap kelangsungan hidup larva udang galah GIMacro II stadia 1 hingga post larvae. Rata-rata kelangsungan hidup perlakuan B lebih baik dibandingkan 


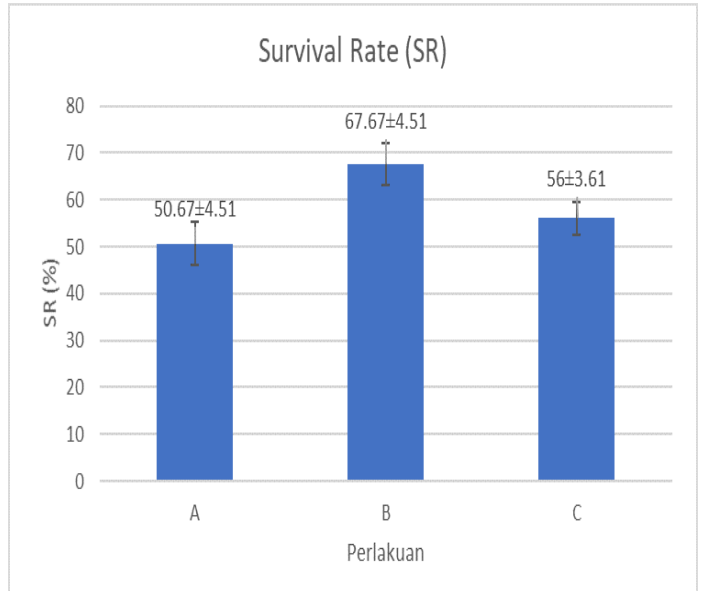

Gambar 3 Tingkat kelangsungan hidup larva udang galah

perlakuan A dan C. Pada perlakuan B dengan nilai osmolaritas media sebesar $311 \mathrm{mmol} / \mathrm{kg}$, udang galah GIMacro II melakukan kerja mendekati isosmotik yang artinya osmolaritas haemolymp hampir sama dengan osmolaritas medianya, hal ini menunjukkan terbukti dengan tingkat kerja osmotik yang paling kecil dibandingkan dengan salinitas 10 ppt dan 14 ppt, sehingga hasil anlisis statistik (Anova) dengan tingkat kepercayaan $95 \%$ menunjukkan perbedaan yang nyata antar perlakuan. Pernyataan tersebut sesuai dengan Ali and Waluyo (2015) yang menyatakan bahwa tingkat kelangsungan hidup udang galah tertinggi diperoleh pada media dengan kisaran salinitas $3-12$ ppt. Hasil uji lanjut Duncan pada taraf kepercayaan $95 \%$ menunjukkan bahwa perbedaan salinitas memberikan pengaruh nyata terhadap tingkat kelangsungan hidup larva udang galah GIMacro II yang mana pada perlakuan B berbeda nyata terhadap perlakuan A dan perlakuan C. Pada perlakuan A menunjukkan tingkat kelangsungan hidup yang lebih rendah dari perlakuan lainnya disebabkan perkembangan yang tidak seragam antar individu sehingga individu yang tumbuh dan berkembang dengan cepat akan menguasai wilayah dan persaingan dalam memperebutkan makanan. Larva udang yang lemah cenderung akan susah mendapatkan makanan dan mudah stress dan terserang penyakit, sehingga kanibalisme pun tidak dapat dihindari (Ali and Waluyo, 2015). Sedangkan pada perlakuan $\mathrm{B}$, tingkat kelangsungan hidup yang didapat lebih tinggi dari perlakuan lainnya disebabkan karena larva udang sudah mampu beradaptasi dengan baik pada lingkungannya sehingga larva udang mampu mendapatkan makanan yang diberikan dengan mudah.

Kehidupan organisme akuatik, termasuk udang galah, sangat ditentukan oleh daya dukung lingkungan, yang salah satunya adalah parameter kualitas air pemeliharaan (Khasani et al., 2018). Selama penelitian dilakukan pengamatan kualitas air yang meliputi suhu air, salinitas, oksigen terlarut, dan $\mathrm{pH}$. Hasil pengukuran parameter kualitas air selama 21 hari pemeliharaan menunjukkan parameter kualitas air dalam batas optimal bagi kehidupan larva udang galah GIMacro II (Tabel 1).

Suhu selama penelitian berkisar antara $28-29^{\circ} \mathrm{C}$. Kisaran suhu tersebut masih dalam kisaran toleransi udang galah GIMacro II. Jika suhu air lebih dari angka tersebut maka metabolisme dalam tubuh udang akan berlangsung cepat. Suhu dapat mempengaruhi berbagai fungsi metabolisme dari organisasi akuatik seperti pertumbuhan dan tingkat konsumsi pakan (Serang et al., 2006). Semakin tinggi suhu maka akan mempercepat proses metabolisme dan meningkatkan konsumsi pakan pada udang sehingga mempercepat pula proses mo- 
Tabel 1 Kualitas air media pemeliharaan udang galah selama penelitian

\begin{tabular}{ccccc}
\hline Parameter & Kisaran Optimum* & A & B & C \\
\hline Suhu $\left({ }^{\circ} \mathrm{C}\right)$ & $27-31$ & $28-29$ & $28-29$ & $28-29$ \\
$\mathrm{pH}$ & $7-8,5$ & $7-7,78$ & $7,73-7,83$ & $7,57-7,81$ \\
$\mathrm{DO}(\mathrm{mg} / \mathrm{L})$ & $1,90-6,98$ & $4,4-5,3$ & $4,8-5,8$ & $4,7-5,5$ \\
Salinitas $(\mathrm{ppt})$ & $8-16$ & 10 & 12 & 14
\end{tabular}

ulting yang akan mempengaruhi pertumbuhan panjang dan beratnya.

Udang galah GIMacro II memiliki toleransi luas terhadap salinitas sehingga udang galah GIMacro II dapat beradaptasi dalam keadaan salinitas yang rendah. Hal ini sesuai dengan pernyataan Ali and Waluyo (2015) bahwa perkembangan dan kelangsungan hidup udang galah yang baik diperoleh pada media dengan kisaran salinitas 3-12 ppt.

Salinitas adalah tingkat kadar garam terlarut dalam air yang merupakan salah satu aspek kualitas air yang memegang peranan penting karena mempengaruhi pertumbuhan udang. Salinitas adalah konsentrasi semua ion-ion terlarut dalam air (klorida, karbonat, bikarbonat, sulfat, natrium, kalsium dan magnesium). Konsentrasi salinitas sangat berpengaruh terhadap proses osmoregolasi yaitu upaya hewan air untuk mengontrol keseimbangan air dan ion antara tubuh dan lingkungannya. Jika kondisi salinitas berfluktuasi maka semakin banyak energi yang dibutuhkan untuk metabolisme. Metabolisme yang dilakukan merupakan bentuk adaptasi (Fujaya, 2004).

Kandungan oksigen terlarut dalam air merupakan faktor kritis bagi kehidupan udang. Oksigen terlarut berperan dalam perkembangan dan kelangsungan hidup organisme akuatik. Kandungan oksigen terlarut juga sangat penting bagi udang galah GIMacro II karena oksigen dibutuhkan untuk proses metabolisme. Pergantian air pada media pe- meliharaan juga membantu meningkatkan oksigen terlarut.

Pada penelitian ini didapatkan nilai kadar oksigen terlarut yang berada pada kisaran 4,48 - 5,58 mg/L. Kisaran yang dihasilkan saat pengukuran kualitas air selama pemeliharaan ini masih dapat ditoleransi bagi kelangsungan hidup udang galah GIMacro II. Semakin besar udang galah GIMacro II maka konsumsi oksigen yang dibutuhkan semakin besar, namun oksigen di dalam media pemeliharaan berkurang. Hal ini dikarenakan aerasi di dalam media pemeliharaan dari awal sampai akhir pemeliharaan udang tetap sama, tetapi kebutuhan oksigen udang galah semakin meningkat seiring dengan peningkatan ukuran tubuhnya. Kadar oksigen terlarut optimum $>3 \mathrm{mg} / \mathrm{L}$ dengan toleransi $2 \mathrm{mg} / \mathrm{L}$. Kandungan oksigen terlarut yang rendah di bawah 1,5 mg/L akan bersifat lethal bagi udang (Maimunah and Kilawati, 2015).

Hasil pengukuran $\mathrm{pH}$ selama penelitian berkisar antara $7-7,83$. pH perairan 6,5 - 8,5 merupakan batas optimum yang memungkinkan udang dapat hidup dan berkembang. Nilai $\mathrm{pH}$ di bawah 4,5 atau di atas 9,0 akan mengakibatkan udang mudah sakit, lemah, dan nafsu makan menurun, bahkan cangkang udang galah cenderung keropos dan berlumut. 


\section{SIMPULAN}

Perbedaan salinitas memberi-kan pengaruh yang nyata terhadap perkembangan dan kelangsungan hidup larva udang galah GIMacro II. Hasil penelitian menunjukkan bahwa salinitas $12 \mathrm{ppt}$ merupakan salinitas terbaik dengan indeks perkembangan larva sebesar 7,13 $\pm 0,03$ $\%$ dan kelangsungan hidup sebesar 67,67 $\pm 4,51 \%$. Berdasarkan penelitian yang telah dilakukan maka penulis menyarankan dalam kegiatan pembenihan larva udang galah GIMacro II menggunakan salinitas $12 \mathrm{ppt}$.

\section{Pustaka}

Ali, F. and Waluyo, A. (2015). Tingkat kelangsungan hidup dan pertumbuhan udang galah (macrobrachium rosenbergii de man) pada media bersalinitas. LIMNOTEK-Perairan Darat Tropis di Indonesia, 22(1).

Fujaya, Y. (2004). Fisiologi ikan dasar pengembangan teknik perikanan. Rineka Cipta. Jakarta, 179.

Hana, G. C. (2007). Respon udang vanname (litopenaeus vannamei) terhadap media bersalinitas rendah.

Khasani, I., Imron, I., Suprapto, R., and Himawan, Y. (2018). Evaluasi keragaan persilangan udang galah (macrobrachium rosenbergii) dari beberapa sumber populasi. In Prosiding FORUM INOVASI TEKNOLOGI AKUAKULTUR, pages 581590.

Maimunah, Y. and Kilawati, Y. (2015). Kualitas lingkungan tambak insentif litapenaeus vannamei dalam kaitannya dengan prevalensi penyakit white spot syndrome virus. Research Journal of Life Science, 2(1):50-59.
Mukti, A. T. and Satyantini, W. H. (2016). Peranan l-carnitine pada perkembangan dan pertumbuhan larva udang galah, macrobrachium rosenbergii de man. Jurnal Ilmu-Ilmu Perairan dan Perikanan Indonesia, 12(1):23-26.

Nugrahaningsih, K. A. (2008). Pengaruh tekanan osmotik media terhadap tingkat kelangsungan hidup dan pertumbuhan benih ikan patin (pangasius sp.) pada salinitas 5 ppt.

Priyono, S. B., Sukardi, S., and Harianja, B. S. (2011). Pengaruh shelter terhadap perilaku dan pertumbuhan udang galah (macrobrachium rosenbergii). Jurnal Perikanan Universitas Gadjah Mada, 13(2):78-85.

Serang, M., Suprayudi, M., Jusadi, D., and Mokoginta, I. (2006). Pengaruh kadar protein dan rasio energi protein pakan berbeda terhadap kinerja pertumbuhan benih rajungan (portunus pelagicus). Bogor: Tesis. Institut Pertanian Bogor.

Supono, S. (2017). Studi keragaan udang windu (penaeusmonodon) dan udang putih (litopenaeusvannamei) yang dipelihara pada tambak semi plastik. In Prosiding Seminar Nasional Teknologi Pertanian.

Syafei, L. S. (2006). Pengaruh beban kerja osmotik terhadap kelangsungan hidup, lama waktu perkembangan larva dan potensi tumbuh pascalarva udang galah.

Zikri, O., Hukama Taqwa, F., et al. (2014). Penentuan pola perubahan salinitas pada penetasan dan pemeliharaan larva udang galah (macrobrachium rosenbergii) asal sumatera selatan. Jurnal Akuakultur Rawa Indonesia, 1(1):46-56. 
